\title{
The People's Republic of China and Latin America: the impact of Chinese economic growth on Latin American exports
}

\author{
Daniel E. Perrotti
}

ABSTRACT

The role of the People's Republic of China in the world economy has grown substantially in recent decades, turning it into a strategic foreign trading partner for much of Latin America. Bilateral trade between the region and China totalled US\$ 120 billion in 2009. This study analyses the income elasticity of the region's exports to the country. The findings show that, assuming real gross domestic product (GDP) growth in China of about $7 \%$ a year, the value of Latin American exports to China (at 2005 prices) can be expected to increase by an average of about 10\% a year between 2014 and 2019. In a more conservative scenario of $4.5 \%$ average annual growth in the Chinese economy over the period, exports would rise by about $7 \%$ a year.

KEYWORDS

JEL CLASSIFICATION

AUTHOR
International trade, international economic relations, economic growth, exports, trade statistics, mathematical modelling, Latin America, China

F10, F17, F60

Daniel E. Perrotti is an official with the Latin American and Caribbean Institute for Economic and Social Planning (ILPES) of ECLAC and a regular associate professor with the Faculty of Economic Sciences of the University of Buenos Aires (UBA), Argentina. daniel.perrotti@cepal.org 


\section{I}

\section{Introducción}

This study estimates the income elasticity of Latin American exports to the People's Republic of China ${ }^{1}$ for a set of 17 countries in the region, taking into account the dynamic aspects of exports while also considering the control variables customarily specified in the international trade literature.

$\square$ The author is grateful for the comments and suggestions of René Hernández, an ECLAC staff member, and Rhys Jenkins, a professor at the University of East Anglia in the United Kingdom, and for the suggestions of an anonymous reviewer.

${ }^{1}$ Hereinafter simply China.
With this end in view, section II provides a brief description of the impact China is having on the world economy and its relationship with Latin America. Section III then reviews the literature in the light of the objectives of this study and touches on gravity models. Section IV presents the variables considered in the models, followed by the results of the two estimations carried out (for exports in general and by product type).

Lastly, section V offers some conclusions drawn from the findings of this study.

\section{II}

\section{The Asian giant}

The role of China in the world economy has increased substantially over the last three decades. In that time, it has achieved double-digit annual gross domestic product (GDP) growth, enabling it to increase per capita GDP tenfold and lift 500 million people out poverty. ${ }^{2}$ China has also become the world's second-largest economy, if GDP is measured at purchasing power parity.

Not only does China account for an enormous share of global production, consumption and trade, but it is one of the most important actors in the global financial system, being the largest holder of United States Treasury Bonds. The country has even been promoting the yuan as an alternative international reserve currency (Rosales and Kuwayama, 2012).

The size and impact of China's international trade can be appreciated in different ways. One is to consider that the country became the world's largest goods exporter in 2009 (US\$ 1.202 trillion dollars' worth), ${ }^{3}$ accounting for $9.6 \%$ of world exports. It has also been

\footnotetext{
2 Growth and social inclusion have not led to improvements in the Gini coefficient, however, as inequalities between the seaboard and inland China have increased (Rosales and Kuwayama, 2012).

3 China's exports are clearly differentiated by province and city of origin. The four leading provinces (Guangdong, Jiangsu, Zhejiang and Shandong), together with the city of Shanghai, originated over $75 \%$ of the country's total exports in 2007 (Rosales and Kuwayama, 2012).
}

playing a major role as an importer, being second in the world only to the United States, so that in 2009 it accounted for $8 \%$ of global imports (Rosales and Kuwayama, 2012).

Besides the export dynamic, another driver of the Chinese economy over the past decades has been the focus on investment as a driver of growth, ${ }^{4}$ to such an extent that the consumption to GDP ratio in China is among the lowest of any leading world economy. Over recent years, however, China has oriented its economic policy towards the goal of energizing domestic consumption. ${ }^{5}$

Where supply is concerned, the Chinese economy has continued to increase its agricultural output, which now exceeds even that of the United States and the European Union, and has expanded its share of the mining sector. China generates about $21 \%$ of the world's agricultural value added, and its main agricultural products include cotton and rice (over $30 \%$ of the world total in both cases) and maize (over $20 \%$ of the world total). Its output of

\footnotetext{
${ }^{4}$ Gross fixed capital formation (GFCF) represents about $40 \%$ of Chinese output, and the share rose in 2009 because of stimulus packages for infrastructure investment. The contribution of public consumption also grew (Rosales and Kuwayama, 2012).

${ }^{5}$ See, for example, "China vows to boost domestic consumption", at [online] http://www.usatoday.com/story/money/business/2013/04/17/ china-consumption/2089959/.
} 
soya meal and soya oil also exceeds $20 \%$ of the world total (Rosales and Kuwayama, 2012).

China is not just synonymous with the primary sector, however. On the contrary, it is one of the world's main generators of manufacturing value added in sectors of differing technology intensity. There has also been substantial progress in the service sector, where China has increased its efficiency, especially in trade-related services (transport, physical infrastructure, communications and business and professional services, including financial services) (Rosales and Kuwayama, 2012).

The role of the Chinese economy as a major world consumer is also substantial: China buys $53 \%$ of all soybeans sold on the international market, $28 \%$ of soya oil and $23 \%$ of cotton, while it is the world's leading consumer of coal, tin, zinc and copper. With regard to these last, its share of worldwide minerals and metals consumption in 2009 was about $40 \%$ for lead, nickel, tin, zinc, primary steel, refined copper and aluminium. That same year, it accounted for $10 \%$ of global crude oil consumption (Rosales and Kuwayama, 2012).

\section{The relationship between China and Latin America}

China represents a strategic partner for Latin America. Bilateral trade between the two increased greatly over the first decade of the twenty-first century, totalling US\$ 120 billion in 2009. In addition to the other effects of rising trade volumes, some of the Latin American countries obtain revenues from export duties, which have played an important role in enabling them to sustain their fiscal accounts, hold down public borrowing and build up international reserves (Rosales and Kuwayama, 2012).

In bilateral trade, exports to China as a share of the total exported by the Latin America region rose from an average of $1.7 \%$ in the 1990 s to $9.4 \%$ in the first decade of the twenty-first century (COMTRADE, undated).

This trade has mainly consisted in exports of commodities and minerals by Latin America (chiefly soya, metals and oil) and imports of manufactured goods from China. Regarding this trade pattern, Rosales and Kuwayama (2012) note that "one major challenge is to prevent the growing trade with China from reproducing and entrenching a centre-periphery trade pattern in which China emerges as a new centre and the countries of the Latin American and Caribbean region as a new periphery".

China's demand for Latin American commodities has resulted from its industrialization process, in which metals have played a preponderant part (Jenkins, 2011). The dynamism of this process has not only led to a rise in the quantity of demand, but has also placed strong upward pressure on commodity and mineral prices, resulting in a substantial increase in the terms of trade for many countries of Latin America.

According to the study by Jenkins (2011), the "China effect" 6 on global demand has been felt most strongly in the case of minerals and metals, since "China has reached a level of income at which metal use relative to GDP tends to rise significantly. This has been a result of the rapid industrialization process in China, which has become increasingly metal-intensive over time as production has shifted from labour-intensive goods (such as clothing) to more capital-intensive sectors (such as electrical and electronics). Demand for metals has also been driven by construction and other infrastructure projects," as detailed in figure $1 .^{7}$

A major drawback of the region's export basket is that it competes directly with those of other countries and regions (such as Australia, Canada, New Zealand and the United States of America, and countries bordering China) to supply China with commodities and minerals (particularly mining, agriculture, fishery and forestry products), since China has considerably diversified its sources of supply (Rosales and Kuwayama, 2012).

Again, behaviour differs within Latin America, particularly between Central America, the Caribbean and Mexico, on the one hand, and South America, on the other. Whereas the latter region, being endowed with abundant natural and agricultural resources, has benefited most (excepting Paraguay) from trade with China and the resultant increase in the terms of trade because of the "China effect" (described in Jenkins, 2011), Central America, the Caribbean and Mexico have not been favoured in their trade with China, since their exports are substitutes for many Chinese exports (especially textiles and manufactures), while they are net importers of natural resources (such as oil).

In particular, Jenkins (2011) classifies countries by the impact of the "China effect" on them, highlighting the substantial benefits obtained by mineral-exporting economies in the region (Chile, Peru and the Plurinational

\footnotetext{
${ }^{6}$ Effect calculated by estimating how much higher world commodity prices were in 2007 than they would have been had demand risen at the same rate in China as in the rest of the world between 2002 and 2007.

${ }^{7}$ In the hypothesis used by Jenkins (2011): "The counterfactual used to calculate the impact of China's exceptional growth on commodity prices assumes that the other factors affecting prices [...], such as shifts in supply curves, exchange-rate alterations and speculation, remain unchanged. In other words, we are interested in how much lower commodity prices would have been in 2007 had China's share of world demand remained at the same level as in 2002, ceteris paribus."
} 
FIGURE 1

\section{Estimated impact of Chinese demand on selected global commodity prices, 2007} $(\text { Percentages })^{\mathrm{a}}$

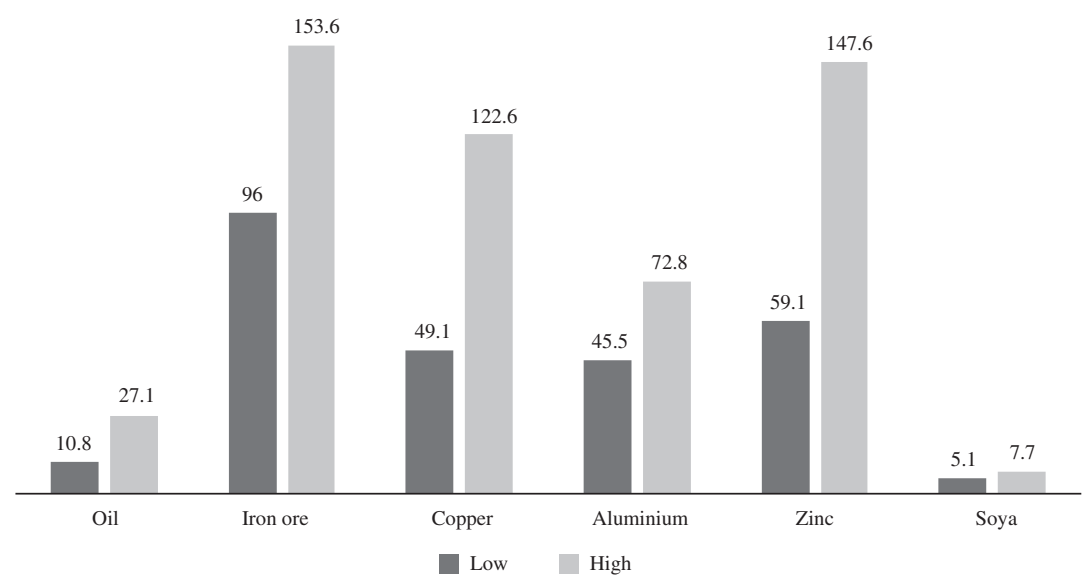

Source: Prepared by the author, on the basis of R. Jenkins, "The 'China effect' on commodity prices and Latin American export earnings", CEPAL Review, No. 103 (LC/G.2487-P), Santiago, Chile, April 2011.

a The chart shows how much higher global commodity prices were in 2007 than they would have been had demand risen at the same rate in China as in the rest of the world between 2002 and 2007.

State of Bolivia). Next come oil exporters (the Bolivarian Republic of Venezuela, Ecuador and Mexico) and the region's two most diversified economies (Argentina and Brazil). In last place are the countries of Central America and the Caribbean, affected by the rise in international commodity and mineral prices, and Mexico, disadvantaged by increased competition from Chinese manufactures in the United States market.

In the recent period, the economic slowdown of 2008-2009 led to an increase in the share of the region's exports going to China, with the share going to the United States diminishing accordingly. This was partly because the Government of China pursued a countercyclical stimulus programme worth US\$ 586 billion during the 2009 international crisis (mainly in the form of infrastructure investment) and thereby managed to avoid any lasting effects from it, so much so that the Chinese economy grew by $9.1 \%$ in 2009 , enabling foreign trade to recover rapidly after the initial negative impact (SELA, 2010).

\section{III}

\section{Literature review}

In consideration of the circumstances mentioned, which demonstrate the growing importance of China as a trading partner for Latin America and its role as a cornerstone of world trade, the present study, as noted in the Introduction, focuses on analysing the income elasticity of Latin American exports to the country, a subject that has been studied in two recent papers.

The first of these, prepared by Nomura (2013), analyses three channels through which a slowdown in the Chinese economy may be transmitted to the rest of the world, namely exports, commodity prices and finance, for a set of 26 countries. After considering these three channels of transmission and comparing a base scenario with a high-risk one,${ }^{8}$ the study finds that a drop of one percentage point in Chinese GDP would reduce economic growth outside the country by 0.3 percentage points of

\footnotetext{
${ }^{8}$ For the estimates in this scenario, Nomura (2013) assumes a drop of between $20 \%$ and $30 \%$ for metal prices and between $15 \%$ and $20 \%$ for the oil price in 2014, taking the average for 2013 as the base.
} 
GDP. In the particular case of Latin America, the effect is found to be even larger, with a 0.5 percentage point drop for every percentage point decline in China's GDP.

The same study notes that China's import elasticity is 4.2, 5.7 and 0.2 for iron, crude oil and copper, respectively. ${ }^{9}$ However, these elasticities are derived from estimates arrived at with simple models that do not consider dynamic effects or other variables besides Chinese GDP growth, in addition to which only a small group of countries is made to stand for Latin America in the publication (Brazil, Colombia, Chile and Mexico).

A document by ECLAC (2012) analyses the impact of global demand and prices for Latin America and the Caribbean's main export products by applying time series autoregressive integrated moving average (ARIMA) models and gravity models. ${ }^{10}$ The study notes that the gravity model served as a basis for calculating the income elasticities of exports from each country in

\footnotetext{
${ }^{9}$ Nomura (2013) states that the negative elasticity of copper may be attributed to the financial trade in the metal in China.

10 The specifications given by the authors for these models are as follows: "For the arima model, monthly data for January 2006 to June 2012 on exports at current values and prices by product category were used to project export volumes for certain groups of products. For the gravity model, annual bilateral trade flows for 1995-2009 were used, together with a set of explanatory variables common to this type of model (GDP, distance, landlocked status, common language, existence of trade agreements)" (ECLAC, 2012, p. 60).
}

\section{IV}

\section{Estimates}

The traditional literature on international trade models is based on so-called gravity models, which were originally introduced into economics by Tinbergen in 1962. They are called "gravity" models by analogy with physics, specifically Newton's law of gravitation, whereby a mass of goods or production factors at a point of origin is attracted by a mass of demand at a point of destination (Anderson, 2010).

In their basic forms, these models set out from the theoretical assumption that trade flows are related directly to the size of the economies of the countries trading and inversely to the distance between them. In general terms, trade $(X)$ is a function of economic "attractors" ( $m$, the countries' GDP), distance $(d)$ and trade policies (p) (De Benedictis and Taglioni, 2011): the region to their main destinations, including China. These elasticities were then used to estimate the volume of exports from the different countries ${ }^{11}$ in 2012-2015, assuming certain GDP projections for the economies of Latin America and the Caribbean and China.

This study employs the gravity model to conclude that the income elasticity of Latin American and Caribbean exports to China is 2.3 , this being the weighted average of the elasticities calculated individually for each country, using exports by destination as weights. China and the rest of Asia have the highest income elasticity for Latin American and Caribbean exports of any region, as can be seen in table 1 .

TABLE 1

Income elasticity of exports from Latin America and the Caribbean

\begin{tabular}{lc}
\hline Country or region & Income elasticity \\
\hline United States & 1.7 \\
Europe & 1.9 \\
People's Republic of China & 2.3 \\
Rest of Asia & 2.3 \\
\hline
\end{tabular}

Source: Economic Commission for Latin America and the Caribbean (ECLAC), Latin America and the Caribbean in the World Economy, 2011-2012 (LC/G.2547-P), Santiago, Chile, 2012. United Nations publication, Sales No. E.12.II.G.5.

11 The study does not list the countries included in the estimates.

$$
X=f(m, d, p)
$$

As a rule, gravity models are estimated transversally, i.e., by taking a diverse set of countries at a given point in time. The present study has departed from this tradition in that the focus of analysis has been placed solely on trade between Latin America and China over a long time period. Naturally, the distance variable has not been considered either, since this remains constant over time.

\section{The variables considered}

As mentioned in the Introduction, the data considered for the estimates include 17 countries in Latin America, namely Argentina, the Bolivarian Republic of Venezuela, 
Brazil, Chile, Colombia, Costa Rica, Ecuador, El Salvador, Guatemala, Honduras, Mexico, Nicaragua, Panama, Paraguay, Peru, the Plurinational State of Bolivia and Uruguay. Time information is annual and covers the period from 1990 to $2013 .^{12}$

For the purpose of ascertaining the income elasticity of exports to China, use was made of a specification encompassing the following variables, which are traditional ones in the economic literature on international trade. In generic terms, the specification is as follows:

where:

$$
\begin{gathered}
x_{i, t}=f\left(y_{t}, \text { tot }_{i, t}, \text { rer }_{i, t}, r_{i, t}\right) \\
++++-
\end{gathered}
$$

(i) $x$ represents exports valued at constant dollars from country $i$ to China in year $t$, as ascertained from the United Nations Commodity Trade Statistics Database (COMTRADE), following the Harmonized System (HS) nomenclature. The series have been deflated using each country's foreign trade deflators (index base $2005=100$ ) as obtained from CEPALSTAT. Figure 2 shows that exports from the region to China grew by an annualized average of $19 \%$ a year between 1990 and 2013, with a particular surge in the first decade of the twenty-first century, when the annualized increase averaged $24 \%$.

12 The period of the sample for the estimates was restricted for methodological reasons that are explained further on, but that stem from the particular concern of the author of this article to estimate elasticities for the period of the great upsurge in trade between Latin America and China in the first decade of the twenty-first century, as discussed by Rosales and Kuwayama (2012). (ii) $y$ is Chinese GDP, measured in billions of yuan at constant values, as ascertained from the World Development Indicators database of the World Bank. Figure 3 shows the uninterrupted growth in the Chinese economy over recent decades, averaging an annualized $10 \%$ between 1990 and 2013 .

(iii) tot is the index for the ratio of trade prices and purchasing power for Latin American exports, measured from base $2005=100$, as obtained from CEPALSTAT. Figure 4 shows that, taking the simple average for the evolution of the terms of trade of all the countries in the sample, there has been a significant positive trend in the evolution of tot since 2003, with some reversals (which have not hitherto affected the trend, however), such as the 2009 crisis and the latest period observed (2012 and 2013), although the figures are still clearly higher than during the 1990s.

(iv) $r e r$ is the bilateral real exchange rate between China and country $i$ (index base $2005=100$ ), obtained from the bilateral nominal exchange rate $\left(n e r^{i}\right)$ deflated by the consumer price index of the country concerned $\left(c p i^{i}\right)$ and indexed by the same price indicator for China (cpichina $)$, as shown in the following equation:

$$
\operatorname{brer}_{i, t}=\frac{n e r_{t}^{i} \cdot c p i_{t}^{\text {china }}}{c p i_{t}^{i}}
$$

The series used to produce this indicator were obtained from the World Bank and CEPALSTAT.

FIGURE 2

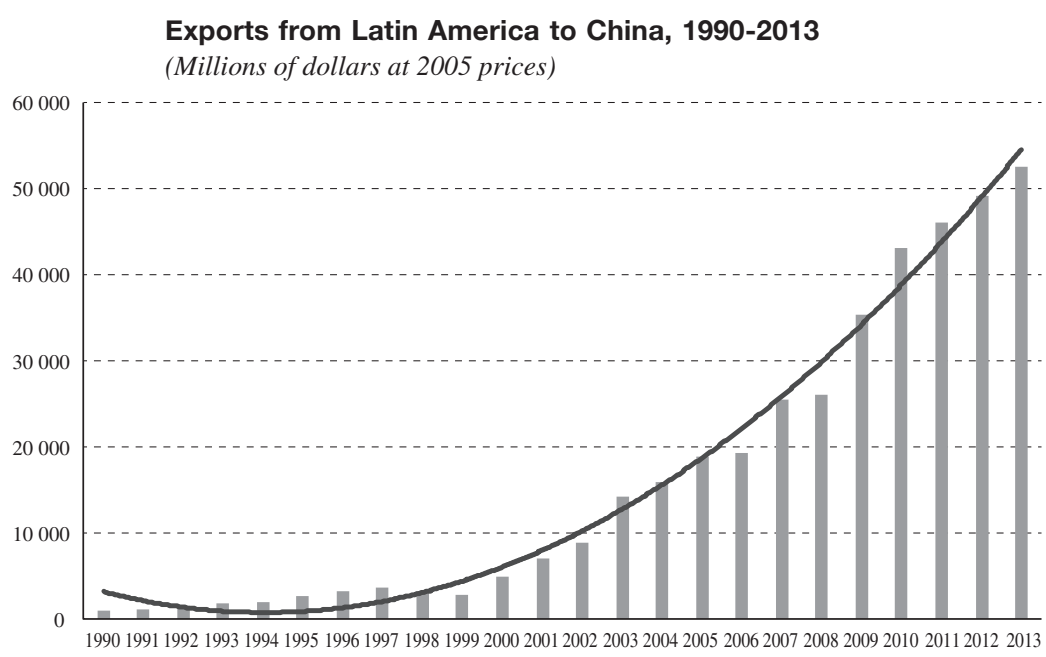

Source: Prepared by the author, on the basis of information from the United Nations Commodity Trade Statistics Database (COMTRADE). 
FIGURE 3

China: gross domestic product (GDP), 1990-2013

(Billions of yuan at constant prices)

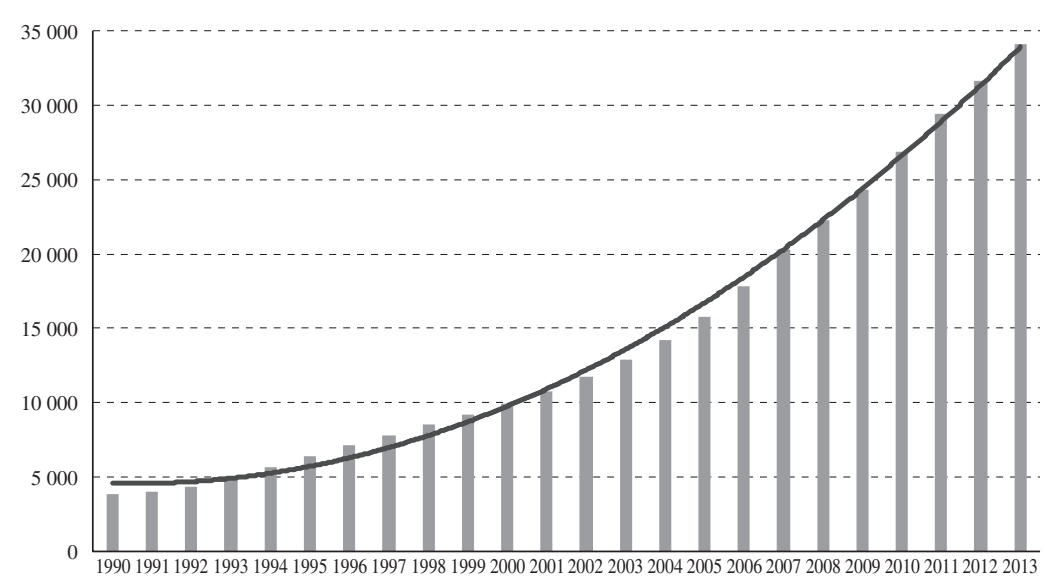

Source: Prepared by the author, on the basis of World Bank data.

FIGURE 4

Latin America: terms of trade, 1990-2013

(Simple averages, index base $2005=100)$

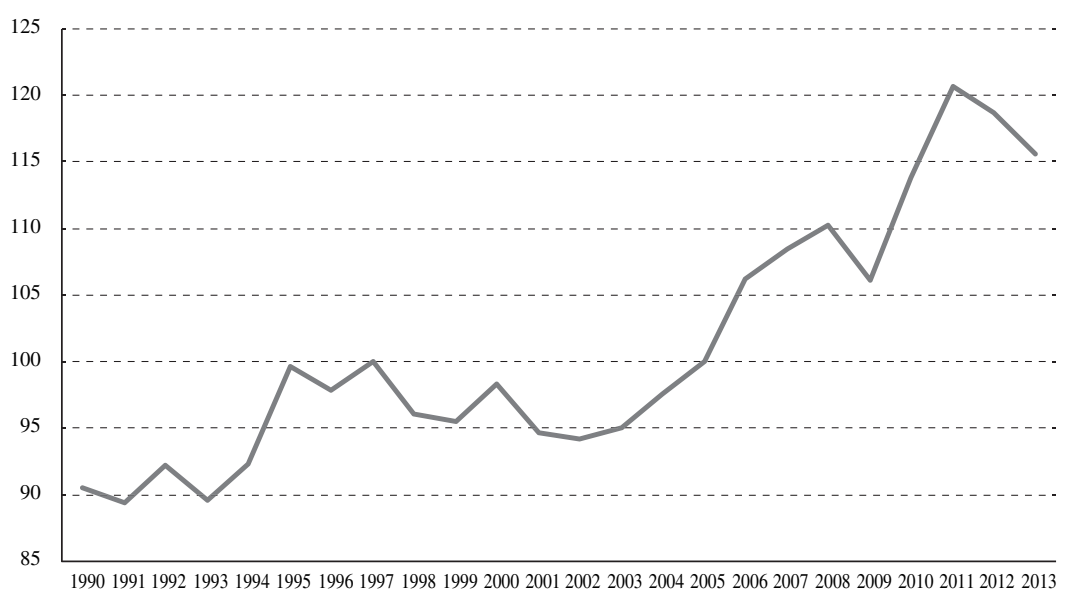

Source: Prepared by the author, on the basis of CEPALSTAT data.

Figure 5 shows that the bilateral real exchange rate of the Latin American countries (calculated as a simple average) was stronger in the first decade of the twenty-first century than in the previous decade. As with real interest rates, which are presented below, reasons for this included the inflow of capital into the region (which strengthened the nominal exchange rate) and greater control of inflation. 
FIGURE 5

Latin America's bilateral real exchange rate with China, 1990-2013

(Simple averages, index base $2005=100$ )

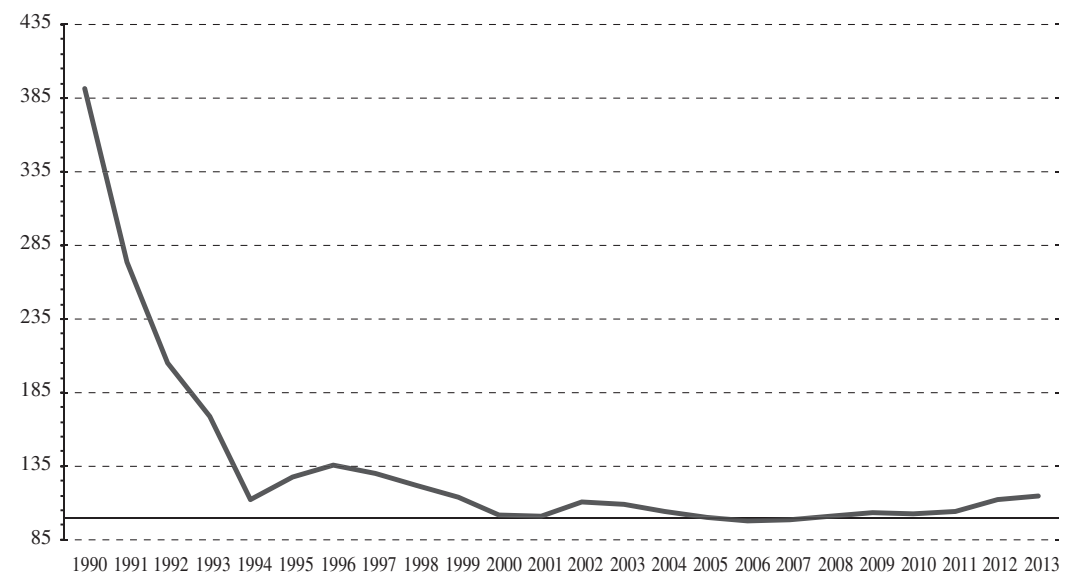

Source: Prepared by the author, on the basis of data from CEPALSTAT and the World Bank.

(v) $r$ is the real interest rate, as obtained from the World Bank database. ${ }^{13}$ Figure 6 shows that the relevant real interest rates in the countries dropped substantially in the latest period (2004 onward), reflecting greater global and regional liquidity, which in turn was contained by inflation rates that were significantly lower than the average for the 1990s. The purpose of including variables other than Chinese GDP is to arrive at a correct specification of the underlying model. When these variables are considered, the relationships expected ex ante are as follows:

- An exogenous increase (decrease) in China's GDP leads, other things being equal, to an increase (decrease) in the country's demand for Latin American exports because income rises (falls).

13 With the exception of Ecuador and El Salvador, for which CEPALSTAT data were used, as the World Bank series for these countries were incomplete.
- An exogenous increase (decrease) in Latin America's terms of trade leads, other things being equal, to an increase (decrease) in Latin America's exports to the country because there is a greater (lesser) incentive to export given the rise (fall) in export earnings and purchasing power.

- An exogenous weakening (strengthening) of the real exchange rate leads, other things being equal, to an increase (decrease) in Latin America's exports to the country, as the competitiveness of products exported to China rises (falls).

- An exogenous increase (decrease) in the real interest rate leads, other things being equal, to a decrease (increase) in the amounts exported to China, owing to a rise (fall) in the opportunity cost.

In the estimations, given that the goal was to estimate elasticities, all variables other than the real interest rate (which has some negative values) have been expressed as logarithms. 


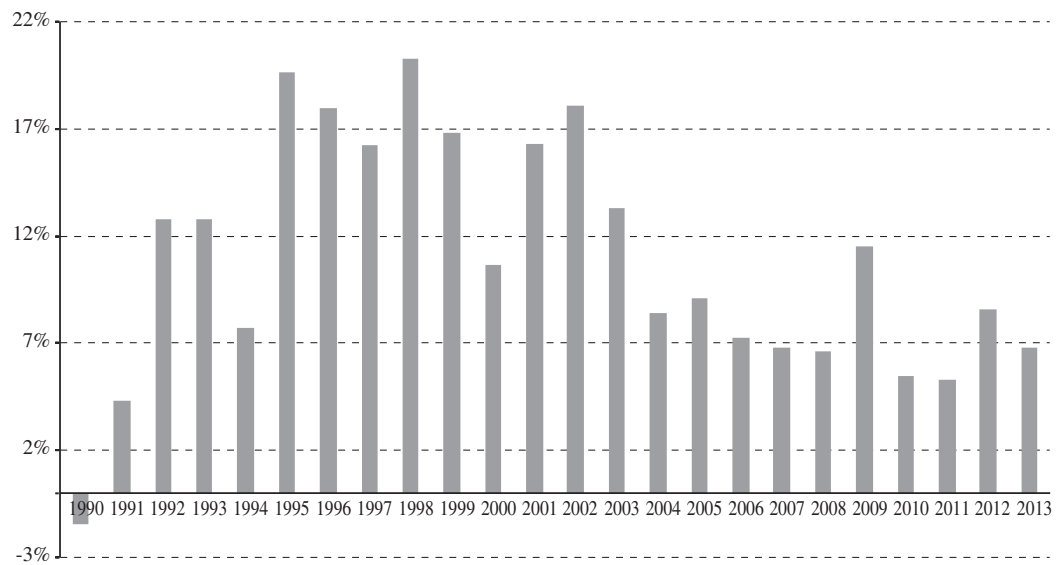

Source: Prepared by the author, on the basis of data from the World Bank.

\section{The estimation strategy}

The estimation strategy chosen for modelling equation (1) was to use a methodology capable of encompassing the dynamic effect of exports to China. The importance of using methodologies of this type is that they yield longterm elasticities which take account of the autoregressive effect deriving from the existence of a degree of continuity in markets for exports between Latin America and China: once commitments have been established between the parties and exporting begins, these commitments usually remain in force for several years. Accordingly, the following specification was determined:

$x_{i, t}=\alpha_{1} x_{i, t-1}+\alpha_{2} y_{t}+\alpha_{3}$ tot $_{i, t}+\alpha_{4} \operatorname{rer}_{i, t}+\alpha_{5} r_{i, t}+\mu_{i, t}$

When models of this type are dealt with, the estimators for ordinary least squares (OLS), fixed effects and random effects are skewed and inconsistent (Hsiao, 1986; Baltagi, 1995). Accordingly, use is made of the estimator developed by Arellano and Bond (1991), whereby the lags of the dependent variable are used as instruments for estimating it.

The Arellano-Bond estimator employs the generalized method of moments (GMM) to estimate a dynamic model of the form:

$$
y_{i, t}=\alpha y_{i, t-1}+\beta x_{i, t}+\mu_{i t}
$$

with

$$
\mu_{i t}=\eta_{i}+\varepsilon_{i, t}
$$

where $y_{i}$, is the variable of interest to be explained by its own lag and by other exogenous variables of interest $\chi_{i}$, . The error term $\mu_{i t}$ is composed of two parts: one with an unobservable component of each cross-section unit (individual effects) $\eta_{i}$ and an idiosyncratic white noise error $\varepsilon_{i, t}$. It is used for long panels with short time periods, and requires there to be no autocorrelation in the idiosyncratic error. The estimator is constructed from first differences to remove the panel-level effects, using instruments to form the conditions of the different moments. The conditions of the moments are formed by the first differences of the error and the other instruments (lagged dependent variables, among others).

The requirement of this class of estimators as regards the size of the panel ( $i$ that are high relative to $t$ ) is directly connected with the intention of the author of the present article to obtain elasticities reflecting the recent boom period with the greatest certainty. Accordingly, while data are available from 1990 onward, the estimations using this methodology were carried out for the sampling period 2003-2013. ${ }^{14}$

In the estimations carried out, all the explanatory variables described in model (1) were considered a priori, although the estimation procedure consisted in progressively discarding those variables that did not evince

\footnotetext{
14 The decision to start the sampling period for the estimates in 2003 was based on two complementary criteria: the considerable dynamism that really began in that year (see Rosales and Kuwayama, 2012), and recovery from the major economic crisis that affected many countries in the Latin America region in 2002.
} 
statistical significance at the usual levels. Consequently, the results presented below only show variables that displayed good statistical behaviour.

\section{(a) Estimation for exports in general}

Following the procedure described in the previous subsection, model (2) was estimated. The results of the estimation, in which the logarithm of total exports from each Latin American country to China in real terms is taken as the dependent variable, are presented in table 2, where it can be seen that the autoregressive component has a very high statistical significance and a memory of 0.47 units for each unit exported in the previous period. Assuming this autoregressive component, the short-term income elasticity of exports is 0.79 percentage points for each percentage point change in Chinese GDP, while long-term elasticity ${ }^{15}$ is 1.51 ; in other words, for each $1 \%$ of additional growth in Chinese GDP, Latin American exports would grow by an average of $1.51 \%$.

TABLE 2

\begin{tabular}{lcc}
\multicolumn{2}{c}{ General model estimation } \\
\hline & \multicolumn{2}{c}{ (Dependent variable: 1real_expo) } \\
\cline { 2 - 3 } & Parameter & Z-statistic \\
\hline lreal_expo (-1) & 0.47 & $7.55 * * *$ \\
lgdp_ch & 0.79 & $-3.33 * * *$ \\
ltot & - & - \\
lrer & - & - \\
r & - & 17 \\
No. of observations & \multicolumn{2}{c}{17} \\
No. of countries & \multicolumn{2}{c}{$2003-2013$} \\
Estimation period & \multicolumn{2}{c}{} \\
\hline
\end{tabular}

Source: Prepared by the author.

Note: $* * *$ Statistically significant at $1 \%$.

lreal_expo: Logarithm of exports.

lgdp_ch: Logarithm of Chinese GDP.

1tot: Logarithm of terms of trade.

lrer: Logarithm of real exchange rate.

$\mathrm{r}$ : Real interest rate.

The Sargan test was then carried out. This tests for overidentifying restrictions under the null hypothesis that the restrictions are valid, i.e., it is a test for the validity of the instrumental variables, checking that these are not correlated with the residuals, and thus that they are valid instruments. The results of this test for the above

15 This is given by: $\frac{\alpha_{2}}{1-\alpha_{1}}$. estimation are presented in table 3, where it can be seen that the model estimated does not reject the null hypothesis that the instruments are valid.

TABLE 3

\begin{tabular}{lc}
\multicolumn{2}{c}{ Sargan test } \\
\hline \\
\hline Chi-squared & Value \\
$p$-value & 170 \\
\hline
\end{tabular}

Source: Prepared by the author.

$\mathrm{H}_{0}$ : Valid restrictions (valid instrumental variables).

$\mathrm{H}_{1}$ : Overidentification.

(b) Estimation by export product type

One thing that needed to be studied were the different elasticities of Latin America's trade with China in relation to the type of export product basket. For this, constant value series were constructed for the following major aggregates: (i) agriculture, hunting, forestry and fisheries, (ii) mining and quarrying and (iii) manufacturing industry, these being baskets that match the major divisions in the nomenclature of the International Standard Industrial Classification of All Economic Activities (ISIC), second revision, as obtained from the Foreign Trade Data Bank for Latin America and the Caribbean (BADECEL) of ECLAC. These series were deflated using the ECLAC external sector commodity price indices, ${ }^{16}$ valued in 2005 dollars.

The countries to be included in each series had to meet both the following methodological criteria: a country belonged in the category if (i) its exports of types a, b and c represented a substantial share $(\geq 10 \%)$ of total exports to China, and (ii) its exports represented at least $0.4 \%$ of total Latin American exports to China in the sector.

Figure 7 shows that virtually the entirety of the region's exports to China during the 1990s came from manufacturing industry, as the sector had a share of $84 \%$ of the total for the three major divisions. This changed sharply with the commodity boom in the early years of the twenty-first century, when mining and quarrying exports and agricultural exports began to become very substantial, accounting between them for much the same share of trade as manufacturing.

16 The price indices were (1) agricultural products, (2) minerals and (3) energy, and they were used to deflate the following series, respectively: (i) agriculture, hunting, forestry and fisheries, (ii) mining and quarrying, and (iii) manufacturing industry. 
The methodology of Arellano and Bond (1991) was once again used in estimating equation (1) by major division. Table 4 presents the results, the main one being that agricultural products have the greatest long-term elasticity (1.60), followed by mining and quarrying products (1.43) and, lastly, industrial products, with an income elasticity of less than $1(0.82)$. Shortterm elasticities maintain the characteristics of their long-term counterparts, with values of $0.95,0.75$ and 0.57 , respectively.

FIGURE 7

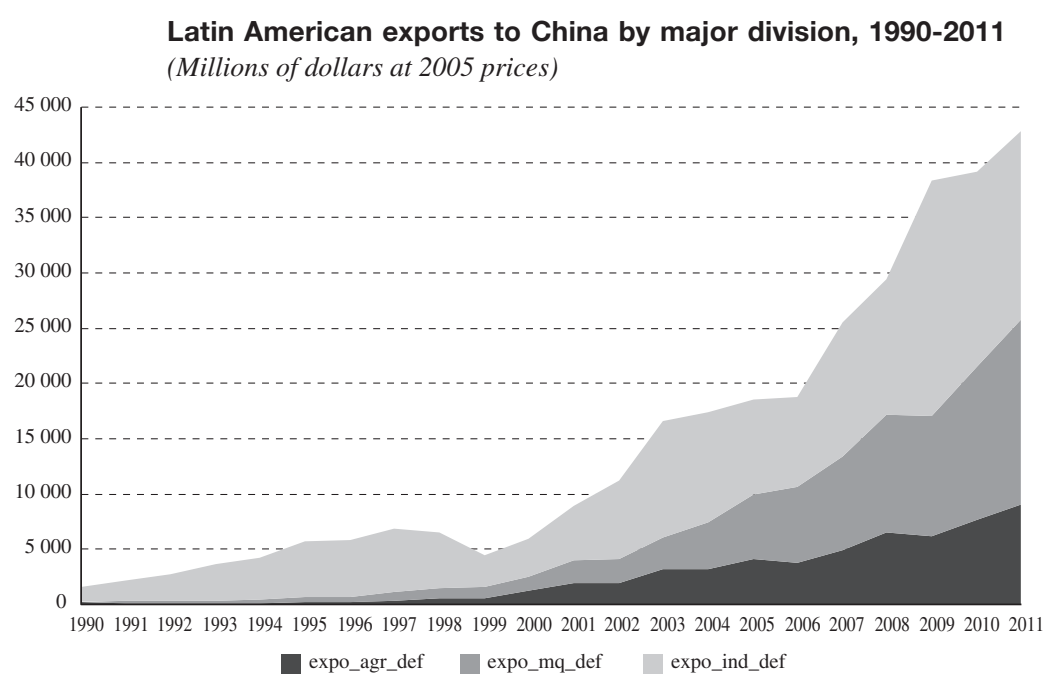

Source: Prepared by the author, on the basis of information from the Foreign Trade Data Bank for Latin America and the Caribbean (BADECEL). Note: expo_agr_def: Agriculture, hunting, forestry and fisheries; expo_mq_def: Mining and quarrying; expo_ind_def: Manufacturing industry.

Model estimations by type of products exported

\begin{tabular}{|c|c|c|c|c|c|c|}
\hline & \multicolumn{2}{|c|}{$\begin{array}{l}\text { Dependent variable: } \\
\text { lexpo_agr_def }\end{array}$} & \multicolumn{2}{|c|}{$\begin{array}{l}\text { Dependent variable: } \\
\text { lexpo_mq_def }\end{array}$} & \multicolumn{2}{|c|}{$\begin{array}{l}\text { Dependent variable: } \\
\text { lexpo_ind_def }\end{array}$} \\
\hline & Parameter & z-statistic & Parameter & z-statistic & Parameter & z-statistic \\
\hline lexpo_x_def $(-1)$ & 0.41 & $3.74 * * *$ & 0.47 & $4.69 * * *$ & 0.30 & $2.74 * * *$ \\
\hline lgdp_ch & 0.95 & $3.23 * * *$ & 0.75 & $1.97 * *$ & 0.57 & $2.05 * *$ \\
\hline ltot & - & - & - & - & - & - \\
\hline lrer & - & - & & & - & - \\
\hline $\mathrm{r}$ & - & - & -3.74 & $-2.80 * * *$ & - & - \\
\hline No. of observations & \multicolumn{2}{|c|}{44} & \multicolumn{2}{|c|}{53} & \multicolumn{2}{|c|}{72} \\
\hline No. of countries & \multirow{2}{*}{\multicolumn{2}{|c|}{5}} & \multicolumn{2}{|c|}{7} & \multirow{2}{*}{\multicolumn{2}{|c|}{8}} \\
\hline Estimation period & & & \multicolumn{2}{|c|}{ 2003-2011 } & & \\
\hline
\end{tabular}

Source: Prepared by the author.

Note: ** Statistically significant at $5 \%$; *** statistically significant at $1 \%$.

lexpo_x_def: Logarithm of exports.

lexpo_agr_def: Logarithm of agriculture, hunting, forestry and fisheries exports.

lexpo_mq_def: Logarithm of mining and quarrying exports.

lexpo_ind_def: Logarithm of manufacturing industry exports.

lgdp_ch: Logarithm of Chinese GDP.

ltot: Logarithm of terms of trade.

lrer: Logarithm of real exchange rate.

r: Real interest rate. 
The results of the estimates directly bear out what might have been expected ex ante in view of the degree of development attained by the Chinese economy during the period analysed and the needs deriving from this, which are consistent with a higher income elasticity for commodities and minerals required in the construction of large cities and as inputs for China's own agricultural production, enabling it to feed the growing population that has been migrating from the rural sector to the new urban centres. Meanwhile, the lower income elasticity found in the estimates for Latin American manufactures shows how large and highly developed this production sector has become in China, and how Chinese manufactures have come to replace Latin American ones in this trade.

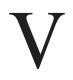

\section{Conclusions}

During the last decade (and particularly since 2003), Latin America's trade with China has become strategic for several countries in the region. Along with other benefits from trade, income from duties on Latin American exports has been a major contributor to the region's fiscal revenue and international reserves.

The first section of this document highlighted the strategic importance of China for Latin America as the recipient for a large share of the region's exports. ${ }^{17}$ Because of this, there is now some concern about the impact China's medium-run performance will have on the region, given that a number of experts have warned of a slowdown from the growth rates seen over the past two decades (Chivakul, 2014).

To respond to the possible impact of this slowdown in Latin America, the present study estimated the long-term income elasticity of the region's exports to China, using dynamic panel data models that follow the methodology set out by Arellano and Bond (1991).

The results yielded by the estimates showed longterm elasticities of over 1 (except in the case of industrial products), albeit with moderate values. The estimates also proved robust to the choice of variables, something that was studied using the Sargan test.

17 This study has not analysed the geopolitical importance of China for the region, or other areas of economic influence, such as Chinese foreign direct investment (FDI) in Latin America.
As in the earlier estimate, the Sargan test was carried out to check for overidentification in the variables used. The test results, shown in table 5, do not reject the null hypothesis that the instruments are valid for the three models estimated.

\begin{tabular}{lccc} 
TABLE 5 & \multicolumn{3}{l}{} \\
& \multicolumn{3}{l}{} \\
\hline Values & Model 1 & Model 2 & Model 3 \\
\hline $\begin{array}{l}\text { Chi-squared } \\
p \text {-value }\end{array}$ & 40 & 61 & 72 \\
& 0.58 & 0.14 & 0.43 \\
\hline
\end{tabular}

Source: Prepared by the author.

$\mathrm{H}_{0}$ : Valid restrictions (valid instrumental variables).

$\mathrm{H}_{1}$ : Overidentification.
When the results obtained are compared with those from other studies that have estimated income elasticities for Latin America's trade with China, the following advances may be noted: the inclusion of a larger number of countries to represent the region (relative to Nomura, 2013) and the specification of an econometric model with dynamic panel data (an advance on ECLAC, 2012).

Looking ahead, the estimates of the International Monetary Fund for the Chinese economy over the next six years (2014-2019) are for average annual growth of 6.8\%. If these projections were borne out, the estimates yielded by the general model indicate that the region's exports to China would grow by about $10 \%$ a year on average. In a more conservative scenario of $4.5 \%$ average annual growth in China over the same period, Latin American exports to the country would grow by about $7 \%$ a year.

The likely dynamic of bilateral trade implies continuing infrastructure and logistics challenges that will have to be dealt with by governments. Some documents (ECLAC, 2010; Perrotti and Sánchez, 2011; Sánchez and Perrotti, 2012) have already warned about the problems of infrastructure shortfalls and their negative repercussions for trade. It is urgent, then, for the countries to make the infrastructure investments needed to avoid potential bottlenecks resulting from external trade in general, and that with China in particular. 


\section{Bibliography}

Anderson, J. (2010), "The gravity model", NBER Working Paper Series, No. 16576, Cambridge, Massachusetts, National Bureau of Economic Research.

Arellano, M. and S. Bond (1991), "Some tests of specification for panel data: Monte Carlo evidence and an application to employment equations", Review of Economic Studies, vol. 58, No. 2, Wiley Blackwell.

Baltagi, B. (1995), Econometric Analysis of Panel Data, Wiley.

Chivakul, M. (2014), "Economic health check: China would benefit from slower but safer growth", International Monetary Fund (IMF), July [online] http://www.imf.org/external/pubs/ft/survey/ so/2014/CAR073014A.htm.

Comtrade (United Nations Commodity Trade Statistics Database) [online] http://comtrade.un.org/data/.

De Benedictis, L. and D. Taglioni (2011), "The gravity model in international trade" [online] http://works.bepress.com/cgi/ viewcontent.cgi?article $=1019 \&$ context=luca_de_benedictis.

ECLAC (Economic Commission for Latin America and the Caribbean) (2012), Latin America and the Caribbean in the World Economy, 2011-2012 (LC/G.2547-P), Santiago. United Nations publication, Sales No. S.12.II.G.5.

(2010), Time for equality: closing gaps, opening trails (LC/G.2432(SES.33/3)), Santiago.

(n/d), "CEPAlstat. Databases and Statistical Publications" [online] http://estadisticas.cepal.org/cepalstat/WEB_cepalstat/ Portada.asp?idioma $=\mathrm{i}$.

Hausman, J.A. (1978), "Specification tests in econometrics", Econometrica, vol. 46, No. 6, New York, The Econometric Society.

Hsiao, C. (1986), Analysis of Panel Data, Cambridge, Cambridge University Press.

IMF (International Monetary Fund) (2014), "The World Economic Outlook Databases" [online] http://www.imf.org/external/ns/ cs.aspx?id=28.

Jenkins, R. (2011), "The 'China effect' on commodity prices and Latin American export earnings", CEPAL Review, No. 103 (LC/G.2487-P), Santiago, April.
Kao, C. (1999), "Spurious regression and residual-based tests for cointegration in panel data", Journal of Econometrics, vol. 90, No. 1, Amsterdam, Elsevier.

Mulder, N. (2006), "Aprovechar el auge exportador de productos básicos evitando la enfermedad holandesa", Comercio Internacional series, No. 80 (LC/L.2627-P), Santiago, Economic Commission for Latin America and the Caribbean (ECLAC). United Nations publication, Sales No. S.06.II.G.151.

Nomura (2013), Global Markets Research. Anchor Report, July.

Perrotti, D. and R. Sánchez (2011), "La brecha de infraestructura en América Latina y el Caribe", Recursos Naturales e Infraestructura series, No. 153 (LC/L.3342), Santiago, Economic Commission for Latin America and the Caribbean (ECLAC).

Rosales, O. and M. Kuwayama (2012), China and Latin America and the Caribbean: Building a Strategic Economic and Trade Relationship, ECLAC Books, No. 114 (LC/G.2519-P), Santiago, Economic Commission for Latin America and the Caribbean (ECLAC). United Nations publication, Sales No. E.12.II.G.12.

(2007), "Latin America meets China and India: prospects and challenges for trade and investment", CEPAL Review, No. 93 (LC/G.2347-P), Santiago, December.

Sánchez, R. and D. Perrotti (2012), "Looking into the future: big full containerships and their arrival to South American Ports", Maritime Policy and Management, vol. 39, No. 6, Taylor \& Francis.

SELA (Latin American Economic System) (2010), Evolución reciente de las relaciones económicas entre la República Popular China y América Latina y el Caribe. Mecanismos institucionales y de cooperación para su fortalecimiento (SP/CL/XXXVI.O/Di No. 12-10), Caracas, October.

Wooldridge, J. (2010), Econometric Analysis of Cross Section and Panel Data, Cambridge, Massachusetts, The мiт Press.

World Bank (2014), "World Development Indicators Database" [online] http://data.worldbank.org/. 